\title{
Occult Hepatitis B Infection in Patients With Cryptogenic Liver Cirrhosis in Southwest of Iran
}

\author{
Seyed Jalal Hashemi ${ }^{1, *}$; Eskandar Hajiani ${ }^{2}$; Abdolrahim Masjedizadeh ${ }^{2}$; Manoochehr \\ Makvandi ${ }^{1}$; Ali Akbar Shayesteh ${ }^{2}$; Seyed Pejman Alavinejad ${ }^{2}$; Ahmad Kadkhodaei ${ }^{2}$; \\ Heshmatollah Shahbazian ${ }^{2}$; Farzad Jasemi ${ }^{2}$; Mohamad Karimi ${ }^{2}$ \\ ${ }_{2}^{1}$ Health Research Institute, Infectious and Tropical Diseases Research Center, Ahvaz Jundishapur University of Medical Sciences, Ahvaz, IR Iran \\ 2 Research Institute for Infectious Disease of Digestive System, Ahvaz Jundishapur University of Medical Sciences, Ahvaz, IR Iran \\ ${ }^{*}$ Corresponding author: Seyed Jalal Hashemi, Health Research Institute, Infectious and Tropical Diseases Research Center, Ahvaz Jundishapur University of Medical Sciences, Ahvaz, \\ IR Iran. Tel:+98-9161110261, E-mail: dorhashemi@gmail.com
}

Received: January 3, 2014; Revised: April 30, 2014; Accepted: May 10, 2014

\begin{abstract}
Background: Chronic hepatitis B virus (HBV) infection has a broad spectrum of manifestation, ranging from silent carrier state to advanced cirrhosis and hepatocellular carcinoma. The persistence of HBV DNA in serum and hepatocytes of the cirrhotic patient could be detected by molecular techniques in spite of negative HBV serologic markers.

Objectives:This case-control study was designed to evaluate the prevalence of occult HBV infection(OBI) in patients with cryptogenic liver cirrhosis in comparison with healthy subjects.

Patients and Methods: Of 165 patients with liver cirrhosis, 50 consecutive patients with cryptogenic cirrhosis and 80 healthy individual without any risk factors as a control group were enrolled in this study. Their sera were tested for HBV DNA using nested PCR method. Results: Of 50 patients with cryptogenic cirrhotic, 36 (72\%) were male. The mean age of patients was $53.34 \pm 14.73$ years; 80 healthy subjects were selected as control group with mean age of $32.65 \pm 8.51$ years; $7(14 \%)$ of the patients with cryptogenic cirrhosis showed positive HBV DNA by PCR, while HBVDNA was negative for the control group ( $\mathrm{P}=0.0001) ; 4(57 \%)$ cases with positive HBV shown by PCR were negative for anti-HBc and anti-HBs tests. The mean level of transaminases was significantly higher in patients with cirrhosis. There were no significant differences in demographic parameters, transaminases level and degree of hepatic failure among cirrhotic patients with and without OBI. Conclusions: The prevalence of OBI was relatively high in patients with cryptogenic cirrhosis. OBI was found among the patients above 40 years old. Prospective cohort studies are needed to evaluate the clinical significance of OBI.
\end{abstract}

Keywords: Liver Cirrhosis; Infection; Hepatitis B

\section{Background}

Hepatitis B virus (HBV) infection is the most common chronic viral hepatitis in the world. It is estimated that 350 million carriers exist in the world and around one million of them die annually (1). About $30 \%$ of the world population has been exposed to HBV (2). The prevalence of HBV infection varies between different countries. Some geographical regions such as China, southeast of Asia, and sub-Saharan Africa are highly prevalent areas with more than $7 \%$ chronic carrier rates, while westEurope and North American countries have less than $2 \%$ chronic carrier rates (low prevalent) (3). The prevalence of HBV infection in Iran varied $2.7 \%$ to $7.2 \%$, but after the national vaccination program it decreased to below $2 \%(4,5)$. Traditionally, chronic HBV infection was expressed as existence of hepatitis B surface antigen (HBsAg) in serum.

Occult HBV infection (OBI) is defined as the presence of HBV DNA in serum, lymphocytes or hepatocytes with undetectable HBsAg in serum (6-8). There are certain evi- dences that OBI may be accompanied with other chronic liver diseases such as HCV infection, nonalcoholic liver disease, HIV infected cases, and hemodialysis patients (9-13). OBI has been reported as an additional risk factor for progression of alcoholic liver cirrhosis, nonalcoholic fatty liver disease, and HIV infection to hepatocellular carcinoma (14-17). The etiologies of chronic liver disease and cirrhosis are not clear in at least $10 \%$ of individuals, so called "cryptogenic liver disease" (18). The prevalence of OBI in cryptogenic chronic liver disease varies 19 - 30\%. In a study in Iran, the prevalence of OBI was $1.9 \%$ in people with cryptogenic chronic liver disease (19), while in some regions of India, the prevalence of OBI in patients with cryptogenic liver cirrhosis was reported 38\% (20). A recent study showed 38\% prevalence of OBI in Iranian patients with cryptogenic cirrhosis (21). Usually, the HBV DNA level in patients with OBI is low and currently, PCR is the only available diagnostic tool to detect HBV DNA in sera of patients with OBI (22).

Copyright (C) 2015, Ahvaz Jundishapur University of Medical Sciences. This is an open-access article distributed under the terms of the Creative Commons Attribution-NonCommercial 4.0 International License (http://creativecommons.org/licenses/by-nc/4.0/) which permits copy and redistribute the material just in noncommercial usages, provided the original work is properly cited. 


\section{Objectives}

The aim of the present study was to compare the prevalence of OBI between patients with cryptogenic liver cirrhosis referred to the hepatology clinics of Ahvaz Jundishapur University, and a group of healthy individuals. Ahvaz is the capital of Khuzestan province, located at the southwest region of Iran with a population of 1.5 million.

\section{Patients and Methods}

In this case-control study, 50 patients with cryptogenic liver cirrhosis, referred to gastroenterology and hepatology clinics of Ahvaz Jundishapur University, were selected during May 2011 to June 2012. Liver cirrhosis was defined if there were compatible liver biopsy or clinical plus imaging and laboratorial evidences in favor of portal hypertension and hepatocellular dysfunction. All the patients underwent comprehensive study to rule out autoimmune, metabolic, drug induced and alcohol-related liver injuries. Viral hepatitis was excluded using negative serological markers for HBV and HCV infections. Cryptogenic liver cirrhosis was defined if the patients had cirrhosis without established specific etiology. The control group was selected from the volunteers who were present in the clinics as relative of patients with non-liver diseases, if they had no risk factor for HBV infection. The proposal was approved by the Ethic Committee of the Vice Chancellor for Research and Technology of Ahvaz Jundishapur University (code $=$ ETH-335).

\subsection{Serology and Biochemical Tests}

After blood collection from each patient, the following tests including alanine aminotransferase (ALT) and aspartate aminotransferase (AST), prothrombin time (PT), bilirubin, serum albumin, complete blood count (CBC) were carried out. The serological HBV markers (HbsAg, HBsAb, anti $\mathrm{HBcIgM}$ and anti $\mathrm{HbcIgG}$ ) tests were performed for each individual and the control group by enzyme-linked immunosorbent assay (ELISA) (Diagnostic BioProbe, Milan, Italy). The serum of the each patient was kept at $-80^{\circ} \mathrm{C}$ prior to performing the PCR tests. Nested PCR amplification assay was used to detect OBI for all the patients as well as the control group (23).

\subsection{DNA Extraction}

A volume of $200 \mu \mathrm{L}$ serum of each patient as well as each individual in the control group was used for extraction of the viral DNA, using high pure nucleic acid kit (Roche Applied Sciences, Germany). Nested PCR was applied for amplification of the $S$ region of the HBV DNA gene using the following primers (24): FHBS1 (244 to 267 position), FHBS2 (255 to 278 position), RHBS2 (648 to 671 position), and HBS1R (668 to 691 position). Five microliter of the extracted DNA from each serum sample was added in a $25 \mu \mathrm{L}$ reaction mixture containing dNTP (10 $\mathrm{mM}) 0.5 \mu \mathrm{L}$, PCR buffer $(10 \mathrm{x}) 2.5 \mu \mathrm{L}$, Taq DNA polymerase $5 \mathrm{U}$ (Roche, Germany) $0.15 \mu \mathrm{L}, 50 \mathrm{pmol} / \mu \mathrm{L}$ of both FHBS1 (5'-GAG TCA AGA CTC GTG GTG GAC TTC-3') and RHBS1 (5'AAA TKG CAC TAG TAA ACT GAG CCA-3') primers, and distilled water $20.35 \mu \mathrm{L}$.

Using a thermal cycler (Techneco, UK) for the first round of nested PCR, first amplification was carried out with initial denaturation at $94^{\circ} \mathrm{C}$ for five minutes and then by denaturation at $94^{\circ} \mathrm{C}$ for 30 seconds, annealing at $56^{\circ} \mathrm{C}$ for 30 seconds, and extraction at $72^{\circ} \mathrm{C}$ for 30 seconds for a total of 30 cycles. For the second round, $5 \mu \mathrm{L}$ of each PCR product was added to a $25 \mu \mathrm{L}$ reaction mixture, containing dNTP, PCR buffer and Taq DNA polymerase with $50 \mathrm{pmol} / \mu \mathrm{L}$ of each FHBS2 (5'-CGT GGT GGA CTT CTC TCA ATT TTC-3') and RHBS2 (5'-GCC ARG AGA AAC GGR CTG AGG $\left.C C C-3^{\prime}\right)$ primers. The amplification was carried out in the thermal cycler with the same program for the first amplification. Then, $8 \mu \mathrm{L}$ of the nested PCR product ( $417 \mathrm{bp}$ ) was analyzed by agarose gel electrophoresis on $2 \%$ gel in $0.5 \mathrm{x}$ TBE buffer.

\subsection{Statistical Analysis}

The data were presented as mean \pm standard deviation. Pearson chi-Square test or Fisher's exact test was used for categorical variables and students T-test for continuous variables, using SPSS 16 package program for statistical analysis (Chicago, IL, USA). P value more than 0.05 was considered significant.

\section{Results}

Anti-HBC antibody was detected in serums of 10 (20\%) patients with cirrhosis and $8(10 \%)$ healthy subjects $(\mathrm{P}=$ $0.10)$. Anti-HBS antibody was detected in 12 (24\%) of cirrhotic and $18(21 \%)$ of healthy subjects $(\mathrm{P}=0.84)$ (Table 2$)$. Seronegative OBI was noted in 4 (57\%) of our OBI cases. Three OBI cases had positive anti-HBcAb (two cases of IgG and one case of IgM), but none of them had antiHBsAb. All the OBI-infected patients were older than 40 years. There were no significant differences in severity of liver dysfunction parameters, transaminases and demographic variables between cirrhotic patients with and without OBI; however, the duration from diagnosis of cirrhosis to the first sign of decompensation was shorter in patients with OBI $(1.47 \pm 1.283$ years vs. 4.327 \pm 3.92 years, $\mathrm{P}=0.002,95 \% \mathrm{CI}=-4.585$ to -1.230 ) (Table 3 , Figure 1).

A total of 165 cirrhotic patients were evaluated. The most common cause of liver cirrhosis was HBV infection (42\%), followed by cryptogenic cirrhosis (30.3\%) and autoimmune hepatitis (14\%) (Table 1). We found 55 cases with cryptogenic liver cirrhosis, but five of them were excluded because of disagreement with blood sampling. Therefore, 50 cases were evaluated in the study; 36 (72\%) of them were male and the mean age of the patients was $53.34 \pm 14.73$ years (Table 2). According to the Child-Pugh 
Hashemi SJ et al.

scoring system, 22 (44\%) of the cases had Child A, 12 (24\%) had Child B, and 16 (32\%) were in the Child C stage of liver cirrhosis. Eighty healthy subjects including 27 (33.8\%) males with a mean age of $32.65 \pm 8.51$ years were evaluated as the control group and the result of the tests were compared between the two groups.

HBV DNA was found in 7 (14\%) sera of the patients with cryptogenic cirrhosis; 5 (71.2\%) of cases with OBI were male with a mean age of $54 \pm 8.38$ years. None of the healthy controls group had HBV DNA in their sera ( $P$ $=0.001$ ). Anti-HBc antibody was detected in sera of 10 (20\%) cirrhotic patients and $8(10 \%)$ healthy subjects (P $=0.10)$. HBsAb was detected in $12(24 \%)$ cirrhotic and 18 (21\%) healthy subjects $(\mathrm{P}=0.84)$ (Table 2$) ; 4(8 \%)$ of the cases with $\mathrm{OBI}$ were seronegative, $2(4 \%)$ had positive anti-HBcIgG and 1 (2\%) had anti-HBcIgM, but none of them had HBsAb. All the patients with OBI were older than 40 years. There were no significant differences in severity of liver dysfunction parameters and demographic variables among cirrhotic patients with or without OBI; however, the duration from the initial diagnosis of cirrhosis to the first sign of decompensation was shorter in patients with OBI $(1.47 \pm 1.283$ years vs. $4.327 \pm 3.92$ years, $\mathrm{P}=0.002,95 \%$ $\mathrm{CI}=-4.585$ to -1.230 ) (Table 3 and Figure 1 ).

Table 1. Etiologies of Liver Diseases Among the Studied Patients ${ }^{\mathrm{a}, \mathrm{b}}$

\begin{tabular}{lc}
\hline Etiology of Liver Disease & Number of Cases \\
\hline HBV infection & $70(42.4)$ \\
Autoimmune Hepatitis & $23(14)$ \\
HCV infection & $15(9.1)$ \\
Wilson's Disease & $2(1.2)$ \\
Cryptogenic & $55(33.3)$ \\
\hline
\end{tabular}

a Abbreviations: HBV, hepatitis B virus; HCV, hepatitis C virus.

${ }^{b}$ Data are presented as No. (\%).

Table 2. Characteristics of Patients and Control Group ${ }^{a, b}$

\begin{tabular}{lccc}
\hline Variable & Cryptogenic Cirrhosis $(\mathbf{n}=\mathbf{5 0})$ & Healthy Control $(\mathbf{n}=\mathbf{8 0})$ & P Value \\
\hline Age, $\mathbf{y}$ & $53.34 \pm 14.73$ & $32.65 \pm 8.51$ & 0.001 \\
Male & $36(72)$ & $27(33.8)$ & 0.001 \\
ALT IU/L & $39.48 \pm 14.73$ & $28.40 \pm 11.85$ & 0.005 \\
AST IU/L & $57.46 \pm 25.93$ & $24.55 \pm 8.49$ & 0.0001 \\
HBcAb & $10(20)$ & $8(10)$ & 0.100 \\
HBsAb & $12(24)$ & $18(21)$ & 0.843 \\
OBI & $7(14)$ & $0(0)$ & 0.001 \\
\hline
\end{tabular}

a Abbreviations: ALT, alanine aminotransferase; AST, aspartate aminotransferase; HBcAb, Hepatitis B core antibody; HBsAb, Hepatitis b virus surface antibody; OBI, Occult HBV infection.

$\mathrm{b}$ Data are presented as No. (\%) or mean $\pm \mathrm{SD}$.

Table 3. Characteristics of Cirrhotic Patients With and Without Occult Hepatitis B Virus Infection ${ }^{\mathrm{a}}$

\begin{tabular}{lcccc}
\hline Variable & HBV DNA-Positive $(\mathbf{n}=7)^{\mathrm{b}}$ HBV DNA-Negative $(\mathbf{n}=\mathbf{4 3})^{\mathrm{b}}$ & P Value & $\begin{array}{c}\text { 95\% Confidence Interval of } \\
\text { the Difference }\end{array}$ \\
\hline Male & $5(71.2)$ & $31(72.1)$ & 0.90 & -11.42 to 12.96 \\
\hline Age, $\mathbf{y}$ & $54.00 \pm 8.386$ & $8.386 \pm 15.590$ & 0.849 & -18.423 to 9.265 \\
\hline ALT, IU/L & 45.857133 .363 & $38.441 \pm 31.260$ & 0.567 & -1.671 to 39.80 \\
\hline AST, IU/L & $73.8571 \pm 46.8950$ & $54.790 \pm 20.438$ & 0.071 & -40.092 to -1.170 \\
\hline AlkP, IU/L & $197.857 \pm 9.940$ & $218.488 \pm 58.482$ & 0.038 & -0.809 to 0.503 \\
\hline Bilirubin & $1.20 \pm 0.472$ & $1.353 \pm 0.837$ & 0.640 & -0.468 to 0.464 \\
\hline Albumin & $3.628 \pm 0.419$ & $3.630 \pm 0.587$ & 0.994 & -1.284 to 2.877 \\
PT, $\mathbf{s}$ & $15.857 \pm 2.1157$ & $15.0605 \pm 2.59396$ & 0.395 & -15.066 to 23.593 \\
FBS, mg/dL & $102.8571 \pm 21.95$ & $98.860 \pm 23.442$ & 0.675 & -7.126 to 13.160 \\
Cholesterol, mg/dL & $200.714 \pm 13.047$ & $197.697 \pm 12.279$ & 0.553 & -4.585 to -1.230 \\
\hline Time to decompensation, $\mathbf{y}$ & $1.47 \pm 1.283$ & $4.327 \pm 3.920$ & 0.002 & \\
\hline
\end{tabular}

a Abbreviations: ALT, alanine aminotransferase; AST, aspartate aminotransferase; AlkP, Alkaline phosphatase; PT, prothrombin time.

$\mathrm{b}$ Data are presented as mean \pm SD or No. (\%). 


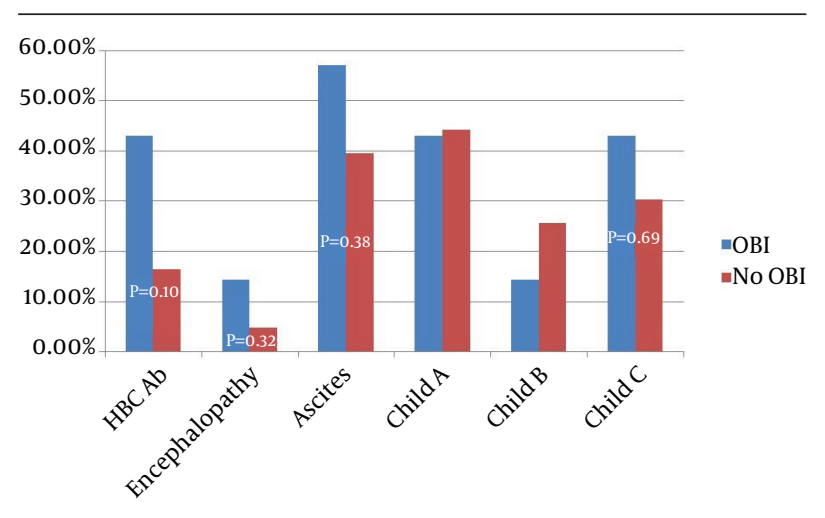

Figure 1. Serological Status and Severity of Liver Failure in Patients With and Without Occult Hepatitis B Virus Infection

\section{Discussion}

In the present study, we investigated 50 patients with cryptogenic cirrhosis and 80 healthy controls to evaluate the prevalence of OBI in the two groups. We found a prevalence of $14 \%$ in patients with cryptogenic liver cirrhosis. All of our OBI cases were over 40 years of age. No patient in the control group was positive for HBV DNA. There have been several studies addressing the prevalence of OBI in Iran with different results. Honarkar et al. evaluated OBI in liver tissues of 35 cases with liver cirrhosis with different etiologies using tissue PCR and reported a prevalence of $22 \%$ (25). Kaviani et al. reported a prevalence of $1.9 \%$ for OBI in 104 patients with cryptogenic chronic hepatitis using real-time PCR (19). Ramezani et al. reported a prevalence of $3 \%$ among 926 high-risk patients, while the prevalence of OBI in the control group was zero (26). Sofian et al. declared a prevalence of $2.1 \%$ for patients with OBI, positive for HBcIgG in 531 blood donors; however, they did not perform PCR for seronegative cases (27).

In our study, 4 (57\%) of seven cases with OBI were negative for $\mathrm{HBcAb}$ and $\mathrm{HBsAb}$ (seronegative); 1 (2\%) of the patients with OBI was positive for anti-HbcIgM, which may be in the window period of acute HBV infection. In this study, we focused on cryptogenic cirrhosis and selected healthy individuals mainly for validation of our tests. Of the control group, 2 (2.5\%) were positive for anti-HBcIgG, but both of them were negative for HBV DNA, which was compatible with other studies in Iran. The prevalence of OBI has been investigated in many countries. While Heringlake et al. (28) did not detect any occult viral infection among 162 presumed cryptogenic liver cirrhosis patients in Germany, Fang et al. (29) reported 28.8\% OBI in 159 Chinese patients. Song et al. from Korea tested 1091 HBsAg-negative adults in the general population and found 7 (0.7\%) OBI cases including five anti-HBcAb negative subjects. In agreement with our study, almost all the cases with OBI in that study were over 40 years old (30). These findings suggest that the epidemiology of OBI is the same as overt HBV infection and national vaccination program may prevent OBI.
Evidences which show high prevalence of OBI among subjects with high-risk behavior support this hypothesis. The prevalence of OBI has been reported to be $41.1 \%$ among four drug abuser in Taiwan and $4.5 \%$ in female workers in Turkey $(31,32)$. Since the viral load in patients with OBI is very low, the estimated prevalence can be affected by the method of HBV DNA testing. Nested PCR is a highly sensitive method for detection of low-level HBV-DNA; it can detect HBV DNA in serum containing more than $19 \mathrm{IU} / \mathrm{mL}$ or 0.1 to $0.01 \mathrm{pg} / \mathrm{L}$ of $\operatorname{HBV}$-DNA $(7,33)$, but may give false positive result due to contamination (24). We considered a control group to address the possibility of contamination and false positive result. We did not detect any positive HBV DNA result is samples of the control group, so the estimated prevalence in our study was scientifically valid. There are several explanations for persistence of $\mathrm{HBV}$ infection without presence of HBsAg in serum samples, including mutation in the $S$ gene causing different or no antigen production (34-36), antigen-antibody immune complex formation with secondary reduction in HBsAg titer to undetectable level (37), HBV-DNA integration into the genome of hepatocytes, and insensitivity of laboratory tests to detect low level antigenemia.

Superimposed or concomitant infection with other viral agents such as HCV and HDV can decrease the HBsAg titer to undetectable levels, and finally in the setting of acute HBV infection, HBS antigen may be undetectable before the appearance of anti-HBsAb (serologic window period) $(38,39)$. There are controversial evidences about the role of OBI in progression of liver dysfunction and development of hepatocellular carcinoma (15). While Covolo et al. (40) and Ikeda et al. (41) in separate studies reported an eight-fold increase in the likelihood of chronic liver disease by OBI, Vakili et al. (42) suggested that OBI may be an insignificant entity. In our study, patients with OBI had statistically non-significant more advanced diseases. For example, they had more frequency, ascites, encephalopathy, and Child C stage of liver cirrhosis ( $\mathrm{P}>$ 0.05) (Figure 1). The duration from the diagnosis of liver cirrhosis to the first sign of decompensation was significantly shorter in infected cases $(1.47 \pm 1.283$ years vs. 4.327 \pm 3.92 years, $\mathrm{P}=0.002,95 \% \mathrm{CI}=-4.585$ to -1.230 ) (Table 3 ). However, the evaluation of these parameters needs greater numbers of positive cases.

In conclusion, our study showed that $\mathrm{OBI}$ is common in patients with cryptogenic liver cirrhosis, especially in older patients. It may contribute to rapid progression to liver decompensation; so, we suggest evaluation of cases with cryptogenic liver cirrhosis for OBI. Infected patient should follow closely for complication.

\subsection{Study Limitations}

Liver biopsy samples were not available for all the cases, so we performed nested-PCR only on serum samples, which may underestimate the prevalence of OBI. The number of positive cases was not sufficient for comparing the clinical implication of OBI on liver cirrhosis. 


\section{Acknowledgements}

This study was the final thesis (code $=9038)$ of Dr. Mohammad Karimi, resident of the Internal Medicine Ward of Jundishapur University of Medical Sciences, Ahvaz, Iran. We thank the participant for their cooperation and give special thanks to Mr. Latifi for statistical analysis of our data.

\section{Authors' Contributions}

Seyed Jalal Hashemi and Heshmatollah Shahbazian designed the study. Manoochehr Makvandi carried out the PCR tests and helped in writing of the manuscript. Eskandar Hajiani, Abdolrahim Masjedizadeh, Farzad Jasemi, Mohamad Karimi, Ahmad Kadkhodaei, Ali Akbar Shayesteh and Seyed Pejman Alavinejad participate in sample collecting and referred cases for the study.

\section{Funding/Support}

The present project was granted by Health Research Institute, Infectious and Tropical Diseases Research Center, Jundishapur University of Medical Sciences, Ahvaz, Iran

\section{References}

1. Lee WM. Hepatitis B virus infection. N Engl J Med. 1997; 337(24):1733-45.

2. Lavanchy D. Hepatitis B virus epidemiology, disease burden, treatment, and current and emerging prevention and control measures. JViral Hepat. 2004;11(2):97-107.

3. Kew MC. Epidemiology of chronic hepatitis B virus infection, hepatocellular carcinoma, and hepatitis B virus-induced hepatocellular carcinoma. Pathol Biol (Paris). 2010;58(4):273-7.

4. Alavian SM, Fallahian F, Lankarani KB. The changing epidemiology of viral hepatitis B in Iran. J Gastrointestin Liver Dis. 2007;16(4):403-6.

5. Merat S, Malekzadeh R, Rezvan H, Khatibian M. Hepatitis B in Iran. Arch Iran Med. 2000;3(4):192-201.

6. Loriot MA, Marcellin P, Bismuth E, Martinot-Peignoux M, Boyer N, Degott C, et al. Demonstration of hepatitis B virus DNA by polymerase chain reaction in the serum and the liver after spontaneous or therapeutically induced HBeAg to anti-HBe or HBsAg to anti-HBs seroconversion in patients with chronic hepatitis B. Hepatology. 1992;15(1):32-6.

7. Torbenson M, Thomas DL. Occult hepatitis B. Lancet Infect Dis. 2002;2(8):479-86.

8. Conjeevaram HS, Lok AS. Occult hepatitis B virus infection: a hidden menace? Hepatology. 2001;34(1):204-6.

9. Raimondo G, Pollicino T, Cacciola I, Squadrito G. Occult hepatitis B virus infection.J Hepatol. 2007;46(1):160-70.

10. Rodriguez-Inigo E, Bartolome J, Ortiz-Movilla N, Platero C, LopezAlcorocho JM, Pardo M, et al. Hepatitis C virus (HCV) and hepatitis B virus (HBV) can coinfect the same hepatocyte in the liver of patients with chronic HCV and occult HBV infection.J Virol. 2005;79(24):15578-81.

11. Chemin I, Zoulim F, Merle P, Arkhis A, Chevallier M, Kay A, et al. High incidence of hepatitis B infections among chronic hepatitis cases of unknown aetiology. J Hepatol. 2001;34(3):447-54.

12. Minuk GY, Sun DF, Greenberg R, Zhang M, Hawkins K, Uhanova J, et al. Occult hepatitis B virus infection in a North American adult hemodialysis patient population. Hepatology. 2004;40(5):1072-7.

13. Tramuto F, Maida CM, Colomba GM, Di Carlo P, Vitale F. Prevalence of occult hepatitis B virus infection in a cohort of HIV-positive patients resident in Sicily, Italy. Biomed Res Int. 2013;2013:859583.

14. Kim MJ, Kwon OS, Chung NS, Lee SY, Jung HS, Park DK, et al. [The significance of anti-HBc and occult hepatitis B virus infection in the occurrence of hepatocellular carcinoma in patients with HBsAg and anti-HCV negative alcoholic cirrhosis]. Korean J Hepatol. 2008;14(1):67-76.

15. Nishikawa H, Osaki Y. Clinical significance of occult hepatitis B infection in progression of liver disease and carcinogenesis. $J$ Cancer. 2013;4(6):473-80.

16. Kitab B, Ezzikouri S, Alaoui R, Nadir S, Badre W, Trepo C, et al. Occult HBV infection in Morocco: from chronic hepatitis to hepatocellular carcinoma. Liver Int. 2014;34(6):e144-50.

17. Huang X, Hollinger FB. Occult hepatitis B virus infection and hepatocellular carcinoma: a systematic review. J Viral Hepat. 2014;21(3):153-62.

18. Berasain C, Betes M, Panizo A, Ruiz J, Herrero JI, Civeira MP, et al. Pathological and virological findings in patients with persistent hypertransaminasaemia of unknown aetiology. Gut. 2000;47(3):429-35.

19. Kaviani MJ, Behbahani B, Mosallaii MJ, Sari-Aslani F, Taghavi SA Occult hepatitis B virus infection and cryptogenic chronic hepatitis in an area with intermediate prevalence of HBV infection. World J Gastroenterol. 2006;12(31):5048-50.

20. Agarwal N, Naik S, Aggarwal R, Singh H, Somani SK, Kini D, et al. Occult hepatitis B virus infection as a cause of cirrhosis of liver in a region with intermediate endemicity. Indian J Gastroenterol. 2003;22(4):127-31.

21. Anvari FA, Alavian SM, Norouzi M, Mahabadi M, Jazayeri SM. Prevalence and molecular analysis of occult hepatitis B virus infection isolated in a sample of cryptogenic cirrhosis patients in iran. Oman Med J. 2014;29(2):92-6.

22. Ocana S, Casas ML, Buhigas I, Lledo JL. Diagnostic strategy for occult hepatitis B virus infection. World J Gastroenterol. 2011;17(12):1553-7.

23. Raimondo G, Allain JP, Brunetto MR, Buendia MA, Chen DS, Colombo M, et al. Statements from the Taormina expert meeting on occult hepatitis B virus infection. J Hepatol. 2008;49(4):652-7.

24. Vincenti D, Solmone M, Garbuglia AR, Iacomi F, Capobianchi MR. A sensitive direct sequencing assay based on nested PCR for the detection of HBV polymerase and surface glycoprotein mutations. J Virol Methods. 2009;159(1):53-7.

25. Honarkar Z, Alavian SM, Samiee S, Saeedfar K, Zali MR. Occult hepatitis B among chronic liver disease patients. Saudi Med J. 2005;26(4):601-6.

26. Ramezani A, Banifazl M, Eslamifar A, Aghakhani A. Serological pattern of anti-HBc alone infers occult hepatitis B virus infection in high-risk individuals in Iran. J Infect Dev Ctries. 2010;4(10):658-61.

27. Sofian M, Aghakhani A, Izadi N, Banifazl M, Kalantar E, Eslamifar A, et al. Lack of occult hepatitis B virus infection among blood donors with isolated hepatitis B core antibody living in an HBV low prevalence region of Iran. Int I Infect Dis. 2010;14(4):e308-10.

28. Heringlake S, Schutte A, Flemming P, Schmiegel W, Manns MP, Tillmann HL. Presumed cryptogenic liver disease in Germany: High prevalence of autoantibody-negative autoimmune hepatitis, low prevalence of NASH, no evidence for occult viral etiology. Z Gastroenterol. 2009;47(5):417-23.

29. Fang Y, Shang QL, Liu JY, Li D, Xu WZ, Teng X, et al. Prevalence of occult hepatitis $\mathrm{B}$ virus infection among hepatopathy patients and healthy people in China. J Infect. 2009;58(5):383-8.

30. Song EY, Yun YM, Park MH, Seo DH. Prevalence of occult hepatitis $\mathrm{B}$ virus infection in a general adult population in Korea. Intervirology. 2009;52(2):57-62.

31. Pinarbasi B, Onel D, Cosan F, Akyuz F, Dirlik N, Cakaloglu Y, et al Prevalence and virological features of occult hepatitis B virus infection in female sex workers who work uncontrolled in Turkey. Liver Int. 2009;29(2):227-30.

32. Lin CL, Liu CJ, Chen PJ, Lai MY, Chen DS, Kao JH. High prevalence of occult hepatitis B virus infection in Taiwanese intravenous drug users. J Med Virol. 2007;79(11):1674-8.

33. He J, Wu J, Du S. [Nested polymerase chain reaction (PCR) and multiple cloned antibody capture PCR for the examination of serum hepatitis B virus DNA in negative hepatitis B surface antigen patients suffering from liver diseases]. Zhonghua Nei Ke Za Zhi.1996;35(8):537-41.

34. Blackberg J, Kidd-Ljunggren K. Occult hepatitis B virus after 
acute self-limited infection persisting for 30 years without sequence variation. J Hepatol. 2000;33(6):992-7.

35. Carman WF. The clinical significance of surface antigen variants of hepatitis B virus. J Viral Hepat. 1997;4 Suppl 1:11-20.

36. Zuckerman AJ. Effect of hepatitis B virus mutants on efficacy of vaccination. Lancet. 2000;355(9213):1382-4.

37. Ackerman Z, Wands JR, Gazitt Y, Brechot C, Kew MC, Shouval D. Enhancement of HBsAg detection in serum of patients with chronic liver disease following removal of circulating immune complexes. J Hepatol.1994;20(3):398-404.

38. Brechot C, Thiers V, Kremsdorf D, Nalpas B, Pol S, PaterliniBrechot P. Persistent hepatitis B virus infection in subjects without hepatitis B surface antigen: clinically significant or purely "occult"? Hepatology. 2001;34(1):194-203.

39. Yoshikawa A, Gotanda Y, Itabashi M, Minegishi K, Kanemitsu K,
Nishioka K, et al. HBV NAT positive [corrected] blood donors in the early and late stages of HBV infection: analyses of the window period and kinetics of HBV DNA. Vox Sang. 2005;88(2):77-86.

40. Covolo L, Pollicino T, Raimondo G, Donato F. Occult hepatitis B virus and the risk for chronic liver disease: a meta-analysis. Dig Liver Dis. 2013;45(3):238-44.

41. Ikeda K, Kobayashi M, Someya T, Saitoh S, Hosaka T, Akuta N, et al. Occult hepatitis B virus infection increases hepatocellular carcinogenesis by eight times in patients with non-B, non-C liver cirrhosis: a cohort study. JViral Hepat. 2009;16(6):437-43.

42. Vakili Ghartavol Z, Alavian SM, Amini S, Vahabpour R, Bahramali G, Mostafavi E, et al. Prevalence of occult hepatitis B virus in plasma and peripheral blood mononuclear cell compartments of patients with chronic hepatitis $\mathrm{C}$ infection in tehran-iran. Hepat Mon. 2013;13(5). 